\title{
Performance and Emission Characteristics Analysis of Dual Fuel Compression Ignition Engine Using Natural Gas and Diesel
}

\author{
Salman Abdu Ahmed ${ }^{1, *}$, Song Zhou $^{1}$, and Yuangqing Zhu ${ }^{1}$,Youming Feng ${ }^{1}$ \\ ${ }^{1}$ College of Power and Energy, Harbin Engineering University, \\ E-mail: *ahmedsalman18@yahoo.com
}

Received 27 May 2017, Revised 29 December 2017, Accepted 04 January 2018

\begin{abstract}
The demand for higher output efficiencies, greater specific power output, increased reliability, and ever reduced emissions has been rising. One promising alternative is the use of a gaseous fuel as partial supplement to liquid fuel. In this study, the effects of diesel-natural gas substitution ratios on the engine performance parameters like brake specific fuel consumption (BSFC), and gaseous emissions of nitrogen oxides $\left(\mathrm{NO}_{\mathrm{X}}\right)$, hydrocarbons (HC), carbon monoxide $(\mathrm{CO})$ and carbon dioxide $\left(\mathrm{CO}_{2}\right)$ were investigated for natural gas-diesel fuel operation and then compared with the original diesel operation. The engine was modeled with GT-Power computational simulation tool. The diesel fuel was injected into the cylinder while natural gas was injected in to air-intake pipe then compressed together with air. The simulation was carried out at constant engine speed of $1800 \mathrm{rpm}$ for four different natural gas fractions $(15 \%, 25 \%$, and $50 \%$ and $75 \%) . \mathrm{NO}_{\mathrm{X}}$ and $\mathrm{CO}_{2}$ emissions decreased sharply by more than $45 \%$ and $50 \%$ respectively in dual-fuel mode when compared to only diesel fuel mode. However, an increase was observed in $\mathrm{CO}$ and $\mathrm{HC}$ emissions in dual fuel mode. The results also indicated that higher BSFC and lower brake thermal efficiency (BTE) in dual fuel mode when compared to those of the corresponding diesel engine.
\end{abstract}

Keywords: Diesel; dual-fuel engine; natural gas; engine performance; emissions.

\section{Introduction}

Due to fast depletion of fossil fuels, Environmental concerns, and increasing oil prices led engine manufacturers to conduct research on viable alternative fuels for meeting sustainable energy demand. Diesel engines are the most efficient combustion engine today and they play an important role in transport of goods and passengers on road and on high seas. They are attractive due to their high power output, good fuel conversion efficiency, relatively low fuel consumption and high durability [1,2]. Even though diesel engines are well known for their higher efficiency and fuel economy their combustion results in the emission of noxious pollutants which have an adverse effect both on the environment and human health [3]. The main pollutants consist of nitric oxide and nitrogen dioxide (NOx), carbon monoxide, unburned hydrocarbons, smoke and particulate matter.

In order to control and minimize emissions the International Maritime Organization (IMO) and other regulatory bodies introduced legislation for limiting nongreenhouse gaseous emissions including $\mathrm{NOx}$ and $\mathrm{SO}_{\mathrm{X}}$, as well as the greenhouse gaseous emissions [4]. In compliance with the strict regulations to control emission a lot of research has been conducted to improve the combustion characteristics, so that to maximize the engine efficiency, thus reducing fuel consumption, and harmful gaseous emissions. One promising alternative is the use of a gaseous fuel as partial supplement to liquid fuel. Gaseous fuels such as natural gas and biogas have a knock resistance which makes them suitable for engines with relatively high compression ratios. Moreover, they have negligible sulfur content and less $\mathrm{CO}_{2}$ unit of energy than gasoline or diesel
[5]. Such operation, known as dual fuel, represents an attractive and flexible means for utilizing a range of gaseous fuels, including natural gas. Natural gas resources are abundant and its combustion results in low levels of pollutant formation. A conventional compression ignition engine can be easily converted to dual fuel engines in order to use natural gas as main fuel and diesel as pilot injection. The dual concept involves the utilization of gaseous fuel by first mixing it with the air intake; ignition of this premixed lean charge is then accomplished by injecting a small quantity of diesel fuel, the pilot, near top dead center of the compression stroke [6-8].

Karagoz et al. [9] converted a CI with a mechanical fuel system in to a common rail fuel system and was modified to be operated with mixtures of diesel and Natural gas. They carried out tests at constant speed of $1500 \mathrm{rpm}$ at full load and their results showed that there was a drop in NOx and soot emissions with $15 \%$ and $40 \%$ of natural gas compared to only diesel fuel. Papagiannakis and Hountalas [10] investigated the characteristics of dual fuel operation when liquid diesel was partially replaced with natural gas under ambient intake temperature in a single cylinder direct injection diesel engine. They showed the effects of liquid fuel percentage replacement by natural gas on engine performance and emissions. Egúsquiza et al. [11] investigated the performance and emission characteristics of a turbocharged and after cooled diesel engine operated with natural gas as primary fuel, and diesel fuel as ignition source. The results showed a reduced NOx emission but at low loads there was higher $\mathrm{CO}, \mathrm{HC}$ emissions and higher BSFC when compared to those of the corresponding diesel engine. Gaba et al. [12] analytically examined the 
performance of a CI engine with the minimum use of diesel engine as pilot fuel and bio-diesel as secondary fuel. They observed a sharp increase in work output as the equivalence ratio increased due to more fuel injection. Ayhan et al. [13] investigated the effects of LPG injection during air inlet period on emissions and performance characteristics. In that study the results showed that 5\% LPG injection gave good reduction in terms of $\mathrm{NO}_{\mathrm{X}}$ and smoke. Kumarswamy and Prasad [14] investigated the performance and emission characteristics of a dual fuel engine working with diesel as primary fuel and ignition source and LPG as secondary fuel with EGR system. Their results showed that reduced NOx emissions while there was high $\mathrm{CO}$ and $\mathrm{HC}$ emissions at low loads.

Bob-Manuel et al. [15] investigated the combustion characteristics of natural gas and hydrogen fueled compression ignition engine operated under stable conditions using either neat or emulsified rapeseed methyl ester (RME) for pilot ignition The results showed reduced $\mathrm{NO}_{\mathrm{X}}$ emissions at all test conditions using natural gas. Singh et al. [16] conducted an experimental research on a single cylinder, four-stroke variable compression ratio, direct injection diesel engine using compressed natural gas (CNG)-Diesel dual fuel mode. In that study they found that there was drastic reduction in $\mathrm{CO}, \mathrm{CO}_{2}, \mathrm{HC}, \mathrm{NOx}$ and smoke emissions in the exhaust of dual fuel engine at all load. Mtui [17] conducted numerical investigations on a large stationary diesel engine dual fueled with natural gas and studied the combustion characteristics and maximum possible natural gas substitution. In that study the results showed that the in-cylinder NOx formation significantly reduced as the quantity of natural gas substitution increased.

Table 1. Engine Parameters.

\begin{tabular}{lc}
\hline Engine parameters & Values \\
\hline Maximum continuous rating & $298 \mathrm{~kW}$ \\
(MCR) & $119 \mathrm{~mm}$ \\
Bore & $175 \mathrm{~mm}$ \\
Stroke & $300 \mathrm{~mm}$ \\
Connecting Rod Length & $11.7 \mathrm{~L}$ \\
Total Displacement & 6 in-line \\
Cylinder Configuration & 13 \\
Compression Ratio & 1 unit \\
Turbocharger & 8 holes \\
Fuel injection nozzle & $1000 \mathrm{bar}$ \\
\hline
\end{tabular}

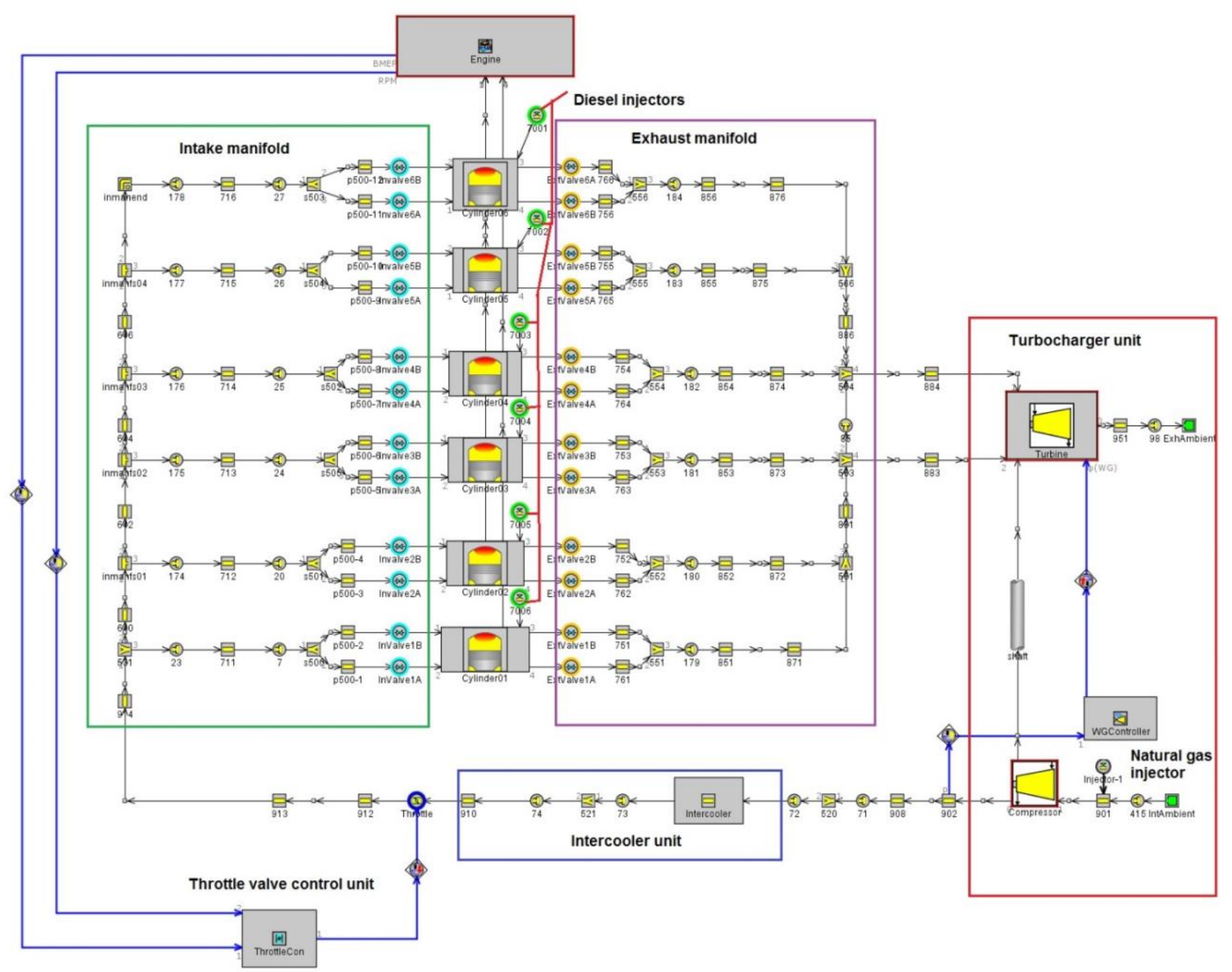

Figure 1. GT-POWER model of the engine. 
The objective of the present work is to investigate the performance and emissions characteristics of a turbocharged diesel engine operated with natural gas and diesel pilot ignition. Natural gas mixture is injected into air-intake pipe of the engine and compressed in the compressor unit then admitted in to the engine cylinders, and ignition is supplied with diesel injection. The effect of different levels of natural gas addition $(15 \%, 25 \%, 50 \%$ and $75 \%)$ on engine performance and emissions characteristics were studied and compared with diesel fuel at constant engine speed of 1800 rpm.

\section{Engine Modeling and Governing Equations}

The engine developed in the present work is a six cylinders, direct injection, turbocharged and in-line engine. The engine used has been modified to operate under dual fuel conditions. The main parameters of the engine are given in Table 1. The software used in the present work is GT-Power, which is widely used 1D simulation program for engine modeling and analysis .It is designed applicable to all types of internal combustion engines. The engine mentioned above was modeled by using different blocks and interconnections that represent the engine layout. The following input data are need to set up the model: the engine geometric data ,the intake and exhaust valve profiles, the compressor and turbine performance maps, the constants of engine sub model (combustion ,heat transfer and friction), the engine operating point (load/speed) and the ambient conditions . The developed GT-POWER model of the engine is shown in Figure 1.

The following assumptions have been made in developing the in-cylinder model for the direct injection dualfuel engine.

I) Cylinder charge is a homogeneous gas mixture of fuel vapor and air, pressure and temperature inside the cylinder are uniform and vary with crank angle,

II) Specific heats of the gaseous mixture are calculated as a function of temperature.

III) The unburned mixture at any instant is composed of air and residual gases without chemical reaction.

IV) No gas leakage through the valves and piston rings so that the mass remains constant.

V) Uniform crank speed (steady state engine) was considered.

VI) The rate of heat transfer of gases to the wall was calculated from the temperature of the combustion gases and the wall. The Woschni heat transfer model was used to calculate the rate of heat transfer cylinder.

The main equations governing the thermodynamic model are the conservation of energy applied to an open system; the equation of ideal gases and the conservation of mass.

The conservation of Energy for an open system is given by Eq. (1) $[18,19]$.

$$
\dot{E}=\dot{Q}-\dot{W}+\sum_{i} \dot{m}_{i} h_{i}
$$

where $\mathrm{E}^{\cdot}$ is the net energy transfer, $\mathrm{Q}^{*}$ is the total heattransfer rate into the system across the system boundary, $\mathrm{W}^{*}$ is the work-transfer rate out of the system across the boundary, $\mathrm{m}^{\circ}$ is the net flux of mass across the system boundaries, $\sum \dot{m}_{i} h_{\mathrm{i}}$ is the enthalpy change through the boundaries per unit time.

The rate of change of mass within any open system is the net flux of mass across the system boundaries. Hence the conservation of mass for a control volume enclosing the airfuel mixture is given by Eq. (2) [18,19].

$$
\dot{m}=\sum_{i} \dot{m}_{i}
$$

The gas species that make up the working fluids in internal combustion engines are treated as ideal gases hence The equation of state for an ideal gases is given by Eq. (3) $[18,19]$.

$P v=R T$

$\mathrm{P}$ is the absolute pressure; $\mathrm{v}$ is the specific volume, $\mathrm{R}$ the gas constant, $\mathrm{T}$ the absolute temperature.

The combustion process in dual fuel engine includes three parts: the diesel premixed combustion, the diesel diffusive combustion and the natural gas premixed combustion [20]. Thus, the total heat release rate of the engine operating in dual fuel mode can be calculated by adding three different single vibe's functions, two for the diesel pilot fuel combustion and one for the natural gas combustion. The total heat release was obtained by adding the individual heat release rates of pilot fuel and natural gas. The heat release rate by diesel, natural gas and the total heat release rate by both diesel fuel and natural gas are given by Eq. (4), Eq. ( 5) and Eq. (6) [21]:

$$
\begin{aligned}
& \mathrm{Q}_{\mathrm{comb}, \mathrm{D}}=\mathrm{m}_{\mathrm{D}} * \mathrm{u}_{\mathrm{D}} *\left[\mathrm{~b}_{1} *\left(1-\mathrm{e}^{-\mathrm{a}^{*}\left(\tau_{\mathrm{D}}\right)^{\mathrm{m}_{1}+1}}\right)+\mathrm{b}_{2} *\left(1-\mathrm{e}^{-\mathrm{a}^{*}\left(\tau_{\mathrm{D}}\right)^{\mathrm{m}_{2}+1}}\right)\right] \\
& \mathrm{Q}_{\mathrm{comb}, \mathrm{NG}}=\mathrm{m}_{\mathrm{NG}} * \mathrm{u}_{\mathrm{NG}} *\left[\mathrm{~b}_{3} *\left(1-\mathrm{e}^{-\mathrm{a}^{*}\left(\tau_{\mathrm{NG}}\right)^{\mathrm{m}_{3}+1}}\right)\right]
\end{aligned}
$$

$\mathrm{Q}_{\text {comb,total }}=\mathrm{Q}_{\mathrm{comb}, \mathrm{D}}+\mathrm{Q}_{\mathrm{comb}, \mathrm{NG}}$

where $\mathrm{Q}_{\mathrm{comb}, \mathrm{D}}, \mathrm{Q}_{\mathrm{comb}, \mathrm{NG}}$ and $\mathrm{Q}_{\mathrm{comb}, \text { total }}$ are the heat released by pilot diesel fuel, heat released by natural gas and the total heat released by both pilot diesel fuel and natural gas respectively. The parameters $b_{1}$ and $b_{2}$ are the weighting factors for the pilot fuel premixed and diffusive combustion parts, $b_{3}$ is the weighting factor for the natural gas premixed combustion; $\mathrm{m}_{1}$, $\mathrm{m}_{2}$ and $\mathrm{m}_{3}$ are the shape factors; $a$ is the Vibe functions parameter considered to be 6.9 for both pilot diesel and natural gas ; $\mathrm{m}_{\mathrm{D}}$ and $\mathrm{m}_{\mathrm{NG}}$ are the injected fuel amount per cycle for the pilot fuel and natural gas, respectively; $u_{D}$ and $\mathrm{u}_{\mathrm{NG}}$ are the effective heat of combustion for the pilot fuel and natural gas, respectively.

The normalized time for pilot fuel and natural gas are given by Eq. (7) and Eq. (8) [21].

$$
\begin{gathered}
\tau_{D}=\frac{\theta-\theta_{0 D}}{\Delta \theta_{b D}} \\
\tau_{N G}=\frac{\theta-\theta_{0 N G}}{\Delta \theta_{b N G}}
\end{gathered}
$$

where $\tau_{D}$ and $\tau_{N G}$ are the normalized time for pilot fuel and natural gas respectively; $\theta_{O D}, \Delta \theta_{b D}, \theta_{O N G}$, and $\Delta \theta_{\mathrm{bNG}}$ are the start of combustion for pilot fuel, combustion duration of pilot fuel, start of combustion of natural gas, and combustion duration of natural gas respectively.

The differential form of the apparent heat release rate and the heat lost to the cylinder walls are given by Eq. (9) and Eq. (10) [19]: 
$\frac{d Q_{n}}{d \theta}=\frac{d Q_{\text {comb,total }}}{d \theta}-\frac{d Q_{h t}}{d t}$

$\frac{d Q_{h t}}{d t}=h_{g} A\left(T_{g}-T_{w}\right)$

where $d Q_{\mathrm{n}}$ is apparent heat release rate, $d Q_{\mathrm{ht}}$ is heat lost to the cylinder walls, $T_{\mathrm{g}}$ is the gas instantaneous temperature, $T_{\mathrm{w}}$ is cylinder wall temperature, $A$ is cylinder heat transfer area, $h_{g}$ is in-cylinder gas to wall heat transfer coefficient.

The Woschni heat transfer model was used to calculate the in-cylinder gas to wall heat transfer coefficient and is given by Eq. (11) [22]:

$h_{g}=130 *\left[B^{-0.2} P^{0.8} u(t)^{0.8} T_{g}^{-0.53}\right]$

where $B$ is cylinder bore diameter and $\mathrm{u}$ is a characteristic velocity. The in-cylinder pressure of the model was given by Eq. (12) $[18,19]$ :

$\frac{d P}{d \theta}=\frac{\gamma-1}{V}\left[\frac{d Q_{\text {comb,total }}}{d \theta}-\frac{d Q_{h t}}{d t}\right]-\gamma \frac{P}{V} \frac{d V}{d \theta}$

where $V$ is the total volume, $P$ is pressure and $\gamma$ is ratio of specific heats at constant pressure and constant volume.

Engine brake thermal efficiency (BTE) and brake specific fuel consumption (BSFC) are given [23] as follows by Eq. (13) and Eq. (14):

$\eta_{B T E}=\frac{P_{b}}{\dot{m}_{D} L H V_{D}+\dot{m}_{N G} L H V_{N G}}$

$B S F C=\frac{\dot{m}_{D}+\dot{m}_{N G}}{P_{b}}$

where $\eta_{\mathrm{BTE}}$ is brake thermal efficiency (BTE), BSFC is the brake-specific fuel consumption, $\mathrm{LHV}_{\mathrm{D}}$ is the lower heating value of diesel fuel and $\mathrm{LHV}_{\mathrm{NG}}$ is the lower heating value of natural gas and $\mathrm{P}_{\mathrm{b}}$ is the brake power.

The $\mathrm{NO}_{\mathrm{X}}$ is produced at a great extent, due to the high local temperatures found in diesel engines which are highly dependent on the initial rise of heat release [19]. Although there are various forms of nitrogen based emissions that comprise Oxides of Nitrogen $\left(\mathrm{NO}_{\mathrm{X}}\right)$, nitric oxide $(\mathrm{NO})$ makes up the majority of all $\mathrm{NO}_{\mathrm{X}}$ emissions produced by the engine. In newer technologies of turbocharged diesel engines, the proportion of $\mathrm{NO}_{2}$ in total $\mathrm{NO}_{\mathrm{X}}$ can be as high as 15 percent or more. $\mathrm{NO}_{\mathrm{x}}$ concentrations in diesel exhaust are typically between 50 and 1000 ppm [24].

The nitric oxide formation was calculated based on the extended Zeldovich [19] mechanism and are given by Eq. (15), Eq. (16) and Eq. (17) [18,19]:

$$
\begin{aligned}
& \mathrm{N}_{2}+\mathrm{O} \underset{\mathrm{k}_{1}^{-}}{\stackrel{\mathrm{k}_{1}^{+}}{\rightleftarrows}} \mathrm{NO}+\mathrm{N} \\
& \mathrm{N}+\mathrm{O}_{2} \underset{\mathrm{k}_{2}^{-}}{\stackrel{\mathrm{k}_{2}^{+}}{\rightleftarrows}} \mathrm{NO}+\mathrm{O} \\
& \mathrm{N}+\mathrm{OH} \underset{\mathrm{k}_{3}^{-}}{\stackrel{\mathrm{k}_{3}^{+}}{\rightleftarrows}} \mathrm{NO}+\mathrm{H}
\end{aligned}
$$

where $\mathrm{k}^{+}$and $\mathrm{k}^{-}$are forward and reverse rate constants and are given as follows $[18,19]$ :

$$
k_{1}^{+}=7.6 \cdot 10^{13} \exp \left(-\frac{38000}{T}\right)
$$

$$
\begin{aligned}
& k_{1}^{-}=1.6 \cdot 10^{13} \\
& k_{2}^{+}=6.4 \cdot 10^{9} T\left[\exp \left(-\frac{3150}{T}\right)\right] \\
& \mathrm{k}_{2}^{-}=1.5^{*} 10^{9} \mathrm{~T}\left[\exp \left(-\frac{19500}{\mathrm{~T}}\right)\right]
\end{aligned}
$$

$\mathrm{k}_{3}^{+}=4.1 \times 10^{13}$

$\mathrm{k}_{3}^{-}=2.0^{*} 10^{14} \exp \left(-\frac{23650}{\mathrm{~T}}\right)$

\section{Results and Discussion}

In this study the effect of different percentages of natural gas $(15 \%, 25 \%, 50 \%$ and $75 \%)$ addition to a diesel fuel on the performance and emission characteristics were investigated at a constant engine speed of 1800rpm.

\subsection{Brake Specific Fuel Consumption and Brake Thermal Efficiency}

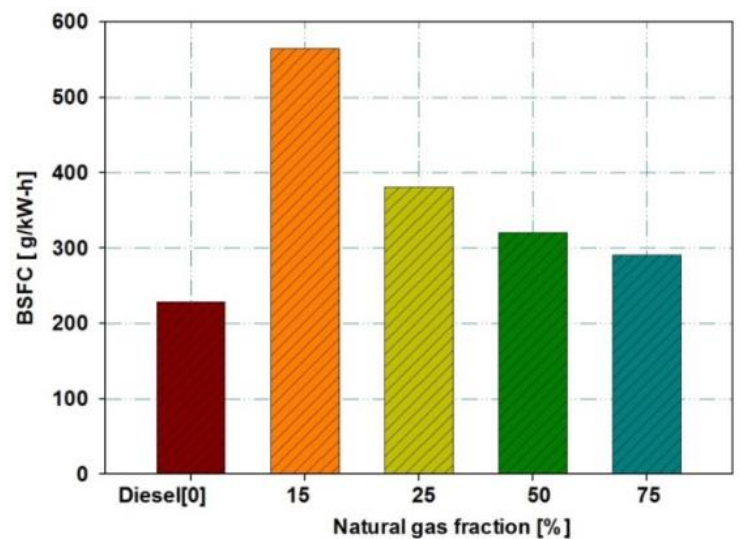

Figure 2. Effect of different amount of natural gas addition on BSFC.

Specific energy consumption is calculated based on fuel consumption and calorific value to the brake power of both diesel and natural gas. Figure 2 shows the effect of the variation of Natural gas fraction on BSFC.BSFC values were higher for all natural gas fractions compared to only diesel fuel, as natural gas quantity increased, BSFC value decreased. BSFC value increased in dual fuel mode when compared to only diesel fuel. The BSFC value was 228 $\mathrm{g} / \mathrm{kW} \mathrm{h}$ when the engine was running on diesel fuel only, but it increased to $564.7 \mathrm{~g} / \mathrm{kWh}, 381.5 \mathrm{~g} / \mathrm{kWh}, 320.8 \mathrm{~g} / \mathrm{kWh}$ and $291.4 \mathrm{~g} / \mathrm{kWh}$ at $15 \%, 25 \%, 50 \%$, and $75 \%$ natural gas respectively. BSFC for dual fuel operation was noticeably higher compared to original diesel operation.

Brake thermal efficiency is one of engine performance parameters that describes the percentage of brake power and fuel energy consumed by the engine and shows how input energy is converted into useful output energy efficiently. Figure 3 shows the effect of Natural gas addition on BTE. It was observed that the BTE was generally lower during dual-fuel operation than diesel fuel mode for instance the BTE values were $13.6 \%, 19.8 \%$, $23.4 \%$, and $25.6 \%$ when the natural gas fraction was $15 \%$, $25 \%, 50 \%$ and $75 \%$ respectively. The BTE values decreased by $62.9 \%, 46 \%, 36 \%$ and $30 \%$ for $15 \%, 25 \%$, $50 \%$ and $75 \%$ natural gas addition respectively when 
compared with neat diesel fuel operation. The slow burning rate resulted in a greater heat loss during combustion thereby decreasing the BTE. Many researchers such as Cheenkachorn et al. [25] Abdelaal et al. [26] and Papagiannakis et al. [27] showed in their experimental investigation that BTE decreased in dual fuel operation which is in line with the results of the present study.

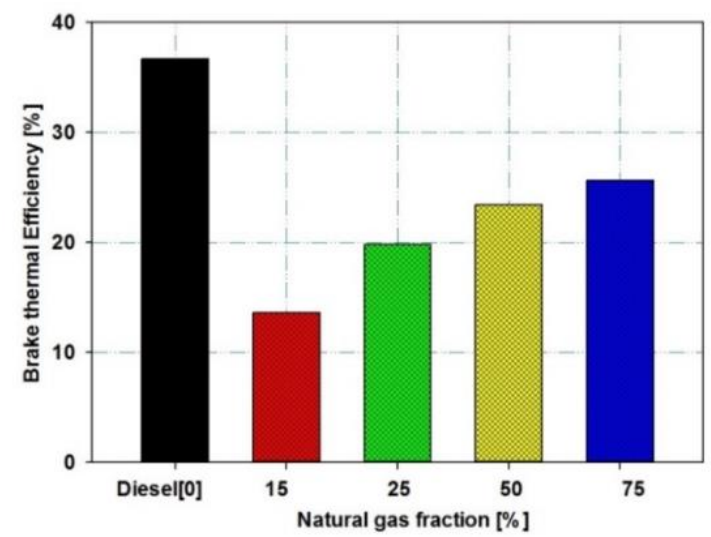

Figure 3. Effect of different amount of natural gas addition on brake thermal efficiency.

\subsection{Nitric Oxide Emissions}

The production of oxides of nitrogen in engine combustion depends primarily on the peak value and distribution of the temperature within the combustion zone and its effective volume, the availability of oxygen, and whether there is sufficient time for the oxygen-nitrogen reactions to proceed to significant levels of completion [20]. The effects of natural gas addition on $\mathrm{NO}_{\mathrm{x}}$ emissions is shown in Figures 4 and 5 respectively. It was observed that there was a significant decrease of $\mathrm{NO}_{\mathrm{x}}$ during dual fuel mode operation. Compared to neat diesel fuel mode there was a decrease in NOx emissions by $62 \%, 58 \%, 52 \%$, and $47 \%$ for $15 \%, 25 \%, 50 \%$ and $75 \%$ natural gas addition fuel respectively for the same engine running conditions. NO formation is affected by in cylinder temperature and oxygen concentration. NO formation occurs when the temperature is above $1800 \mathrm{~K}$. Natural gas injection reduced the amount of air and concentrations of oxygen in the cylinder charge, thereby lowering the formation $\mathrm{NO}_{\mathrm{x}}$. In dual-fuel engines, much less $\mathrm{NO}_{\mathrm{x}}$ is produced than in the corresponding diesel or SI engine operation [20].

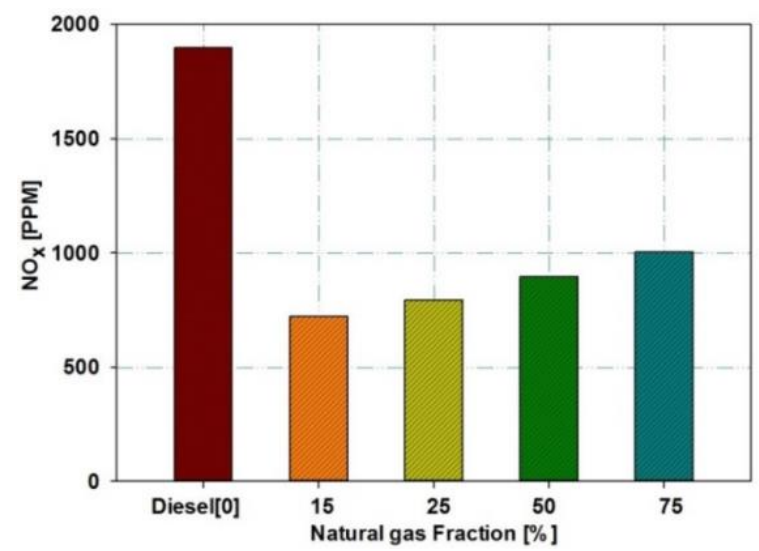

Figure 4. Effect of different amount of natural gas addition on $\mathrm{NO}_{\mathrm{X}}$ emissions.
According to the comparison of $\mathrm{NO}_{\mathrm{x}}$ emission for normal diesel and dual fuel mode made in an experiment conducted by Papagiannakis et al.[10] showed that under all operation loads, $\mathrm{NO}_{\mathrm{x}}$ emission of dual fuel mode was lower than those of normal diesel mode. In an experiment conducted by Liu et al.[28] in a CNG-diesel dual fuel engine showed that $\mathrm{NO}_{\mathrm{x}}$ emission of dual fuel mode was reduced by $30 \%$ averagely in comparison to those of diesel mode. Imran et al.[29] reported significant reduction in $\mathrm{NO}_{\mathrm{X}}$ emission with dual fuel mode compared to normal diesel mode in an experiment they conducted over a wide range of engine speed at both normal diesel mode and natural gas dual fuel mode in a single-cylinder compression ignition engine.In another research conducted by Cheenkachorn et al.[25] on the comparison of $\mathrm{NO}_{\mathrm{X}}$ emission of normal diesel operation and natural gas-diesel dual fuel operation in a heavy-duty diesel engine showed that a significant reduction in $\mathrm{NO}_{\mathrm{x}}$ emission in dual fuel mode when compared to only diesel fuel mode.Based on the research conducted by other researchers most authors showed that lower $\mathrm{NO}_{\mathrm{x}}$ emission with natural gas/diesel dual fuel combustion compared to normal diesel operation. The results obtained in this research are in-line with the experiments conducted by other researchers.

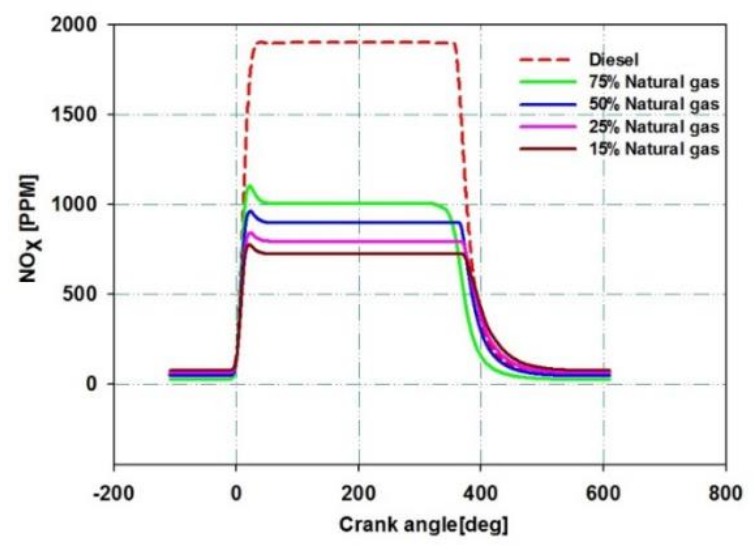

Figure 5. Effect of natural gas addition on $\mathrm{NO}_{X}$ emissions vs. Crank angle.

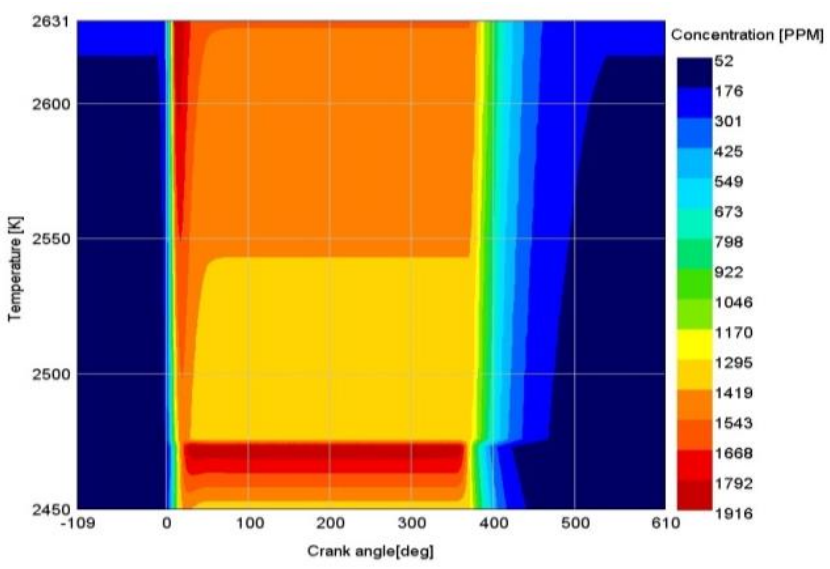

Figure 6. $N O_{X}$ distribution in diesel engine.

$\mathrm{NO}_{\mathrm{X}}$ emissions were reduced when natural gas and diesel fuels were used in combination. One of the marked features of dual fuel operation is that the ignition delay of the pilot fuel is considerably longer than for the original diesel [30]. The increase in the ignition delay would reduce the maximum combustion temperature and, consequently, 
provide lower $\mathrm{NO}_{\mathrm{x}}$ emissions. Another possible explanation is the low concentration of oxygen in the cylinder charge due to the presence of gaseous fuel, which replaces an equal amount of air. The results acquired are in phase with experimental studies conducted by Lounici et al.[31].

Figures 6 and 7 Show the distribution of $\mathrm{NO}_{\mathrm{x}}$ during dual fuel mode and diesel fuel mode operation. As it is clearly indicated the $\mathrm{NO}_{\mathrm{x}}$ concentration was higher when the engine operated with diesel fuel due to the high combustion temperature in the cylinder.

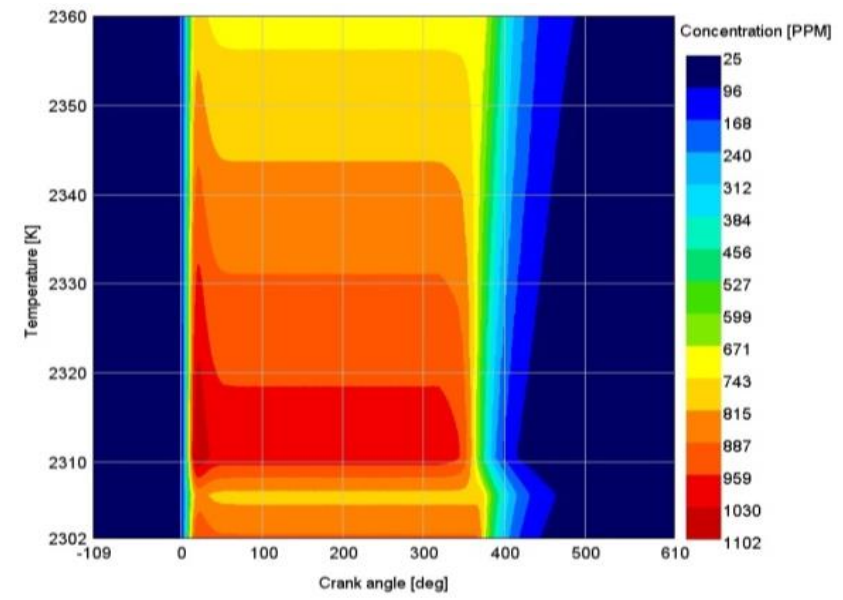

Figure 7. $N O_{X}$ distribution in dual-fuel engine.

\subsection{Carbon Monoxide}

The rate of $\mathrm{CO}$ formation is a function of the available amount of unburned gaseous fuel and of the mixture temperature, both which control the rate of fuel decomposition and oxidation [32]. $\mathrm{CO}$ is formed as a result of incomplete combustion of fuel and is generally formed in rich fuel zone due to lack of oxygen. Figure 8 illustrates the effect of natural gas addition on $\mathrm{CO}$ emissions. The results of the simulation showed that the $\mathrm{CO}$ emissions increased sharply by more than $80 \%$ with the addition of natural gas. The $\mathrm{CO}$ emission for $75 \%$ Natural gas addition was lower by $120 \%, 47 \%$ and $17 \%$ when compared with $15 \%, 25 \%$ and $50 \%$ natural gas addition respectively. It was observed very high $\mathrm{CO}$ emission when the engine operated with $15 \%$ addition of natural gas.

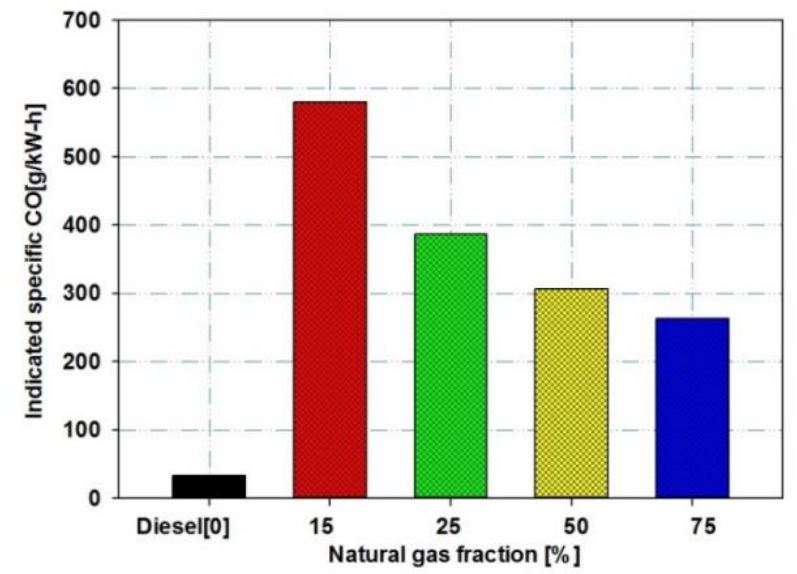

Figure 8. Effect of different amount of natural gas addition on indicated specific $C O$.

Many researchers have also shown that $\mathrm{CO}$ emissions increased in dual fuel mode when compared with neat diesel fuel. In an experiment conducted by Liu et al. [28] in a
CNG/Diesel fuel engine showed that the $\mathrm{CO}$ emission under dual fuel mode was considerably higher than that under normal diesel mode even at high load. In the investigations conducted by Cheenkachorn et al. [25] in a heavy-duty diesel engine working with natural gas/diesel dual fuel found that the dual fuel operation showed significantly high $\mathrm{CO}$ emission for all of the engine speed ranges tested compared to normal diesel fuel operation. Significantly higher $\mathrm{CO}$ emission was also observed by Papagiannakis et al. [27] in a high speed diesel engine operating in natural gas/diesel dual fuel. In the experimental research conducted on the effect of natural gas addition and engine load on the $\mathrm{CO}$ emission by Gatts et al. [33] and Egusquiza et al. [11] showed that a significant increase of $\mathrm{CO}$ emission in dual fuel mode when compared with neat diesel fuel operation. The research conducted by other authors show that a significant increase in $\mathrm{CO}$ emissions under natural gas/diesel dual fuel combustion mode in comparison with normal diesel mode which is in phase with the present work.

\subsection{Hydrocarbon}

Hydrocarbons or, more appropriately, organic emissions are the consequence of incomplete combustion of hydrocarbon fuel [19]. The variation of the indicated specific $\mathrm{HC}$ emissions for different natural gas additions is depicted in Figure 9. As indicated in figure 9, HC emissions under dual fuel operation were considerably higher compared to diesel fuel operation. For instance, HC emissions were $0.82 \mathrm{ppm}, 0.87 \mathrm{ppm}, 0.91 \mathrm{ppm}$ and 0.97 ppm for $15 \%, 25 \%, 50 \%$ and $75 \%$ natural gas addition respectively while that of diesel was $0.10 \mathrm{ppm}$. HC formation in dual fuel operation occurs due to lean mixture of natural gas and air.

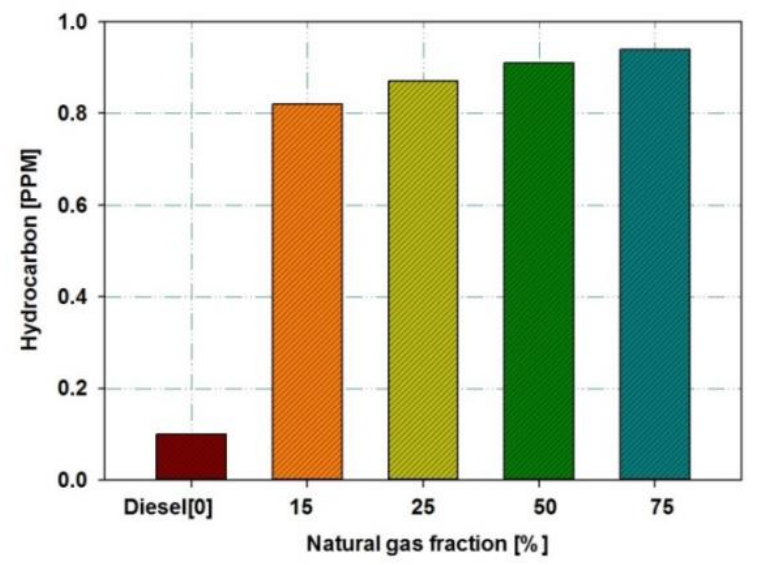

Figure 9. Effect of different amount of natural gas addition on $\mathrm{HC}$.

According to Louniciet al. [31] for all the tested engine speeds, the trend of total hydrocarbon (THC) emissions is similar. At any engine load, THC emissions for dual fuel mode are considerably higher in comparison to those corresponding to conventional diesel case. And according to the experiment conducted made by Cheenkachorn et al. [25] in a heavy-duty diesel engine the results showed that significantly higher $\mathrm{HC}$ emission in dual-fuel mode compared with neat diesel fuel operation. Similarly in the investigation conducted by Egusquiza et al. [11] on the effect of natural gas on $\mathrm{HC}$ emission under various engine loads in a 4-cylinder direct injection diesel engine also showed that considerably higher $\mathrm{HC}$ emission under dual fuel operation compared to diesel operation. As reported by 
Imran et al.[29] there was an increase of HC emission by about $800 \%$ during dual-fuel operation compared to normal diesel mode in the experiment they conducted over a wide range of engine speed and load at both normal diesel mode and natural gas dual fuel mode in a single-cylinder compression ignition engine. Abdelaal et al. [26], Papagiannakis et al. [10,34] and Liu et al. [28]in their study and analysis of natural gas-fueled diesel engine found that the $\mathrm{HC}$ emission with conventional diesel combustion was very low compared to dual-fuel operation. Based on the experiments conducted by various researchers it is very clear that natural gas/diesel dual fuel combustion produces much more HC emission compared to normal diesel combustion which is in consonance with the results of the present work.

\subsection{Carbon Dioxide}

Effect of natural gas addition on $\mathrm{CO}_{2}$ emissions is shown in Figure 10. $\mathrm{CO}_{2}$ emissions decreased with the addition of natural gas. There was a decrease in the $\mathrm{CO}_{2}$ emission by about $59 \%, 53.8 \%, 51.4 \%$, and $49 \%$ for $15 \%$, $25 \%, 50 \%$ and $75 \%$ natural gas addition respectively when compared to only diesel fuel mode. It was observed that for $15 \%$ natural gas addition there was a sharp decrease in $\mathrm{CO}_{2}$ emissions. The results confirm that the use of natural gas in a dual fuel engine reduce $\mathrm{CO}_{2}$ emissions greatly. The main reason for the sharp reduction of $\mathrm{CO}_{2}$ emissions in dual fuel mode was due to low carbon to hydrogen ratio of natural gas.

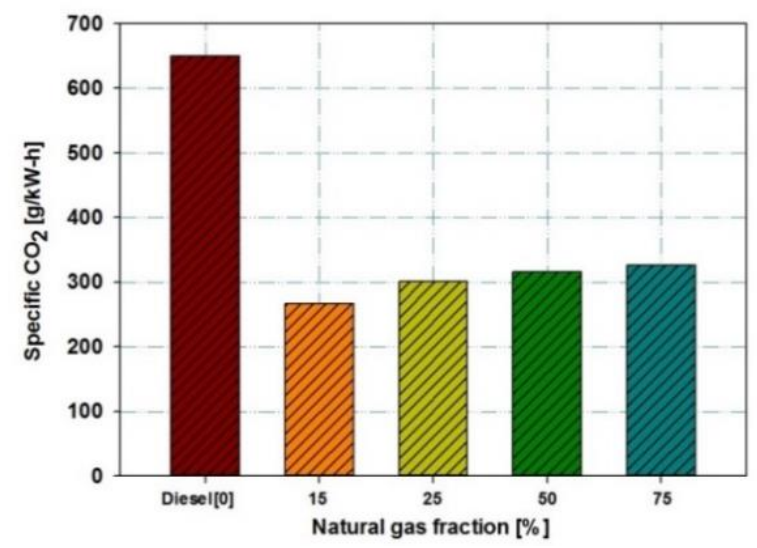

Figure 10. Effect of different amount of natural gas addition on specific $\mathrm{CO}_{2}$.

The results of the simulation are in parallel with the results of the experimental studies conducted by Lounici et al.[31] and E.Ramjee et al.[35].As reported In the experiment conducted on the effects of natural gas on $\mathrm{CO}_{2}$ emission using a heavy-duty diesel engine by Cheenkachorn et al.[25] found that dual fuel operation had lower $\mathrm{CO}_{2}$ emission for all the tested engine speeds compared to neat diesel operation. According to the results of the research conducted by Nwafor et al.[36] showed that a net reduction in $\mathrm{CO}_{2}$ emission was observed under natural gas dual fuel operation compared to the results obtained under neat diesel operation mode. The investigations conducted by Imran et al.[29] on the effect of natural gas addition on $\mathrm{CO}_{2}$ emission found that dual fuel operation produced less $\mathrm{CO}_{2}$ emission due to lower carbon to hydrogen ratio of natural gas. The results of the present work are in total agreement with the research conducted by many researchers that showed significant decrease in $\mathrm{CO}_{2}$ emission with natural gas/diesel dual fuel combustion.

\subsection{Pressure and Heat Release Rate}

Both in-cylinder pressure and temperature are important variables that affect the in cylinder mechanical and thermal stresses. Figure 11 depicts the in-cylinder pressure for the natural gas additions and diesel fuel. According to the results of simulation the maximum in-cylinder pressures were 95.5bar, 116.8bar, 120.3bar, and 127.5bar for $15 \%$, $25 \%, 50 \%$, and $75 \%$ natural gas, respectively. Due to increased heat release of premixed mixture near TDC the maximum in-cylinder pressure increased by $16.5 \%, 19.8 \%$ and $27 \%$ for $25 \%, 50 \%$ and $75 \%$ Natural gas additions respectively when compared to diesel fuel mode however, for $15 \%$ natural gas addition the pressure was lower by $4.8 \%$ than pure diesel fuel.

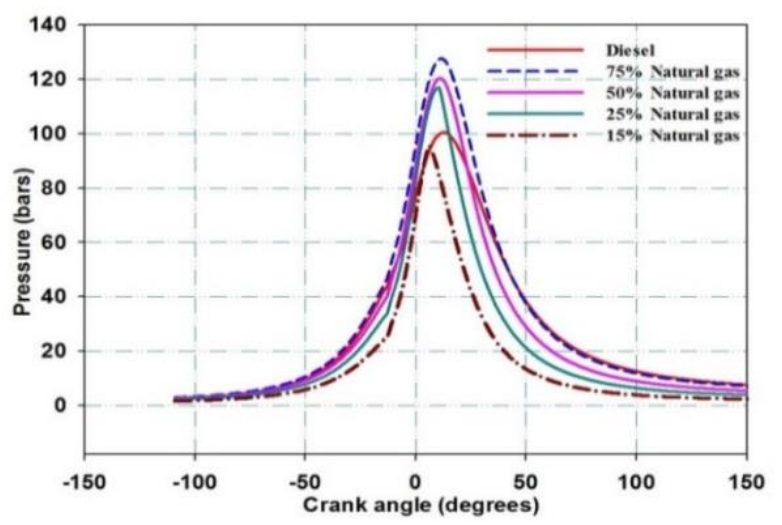

Figure 11. Effect of different amount of natural gas addition on cylinder pressure.

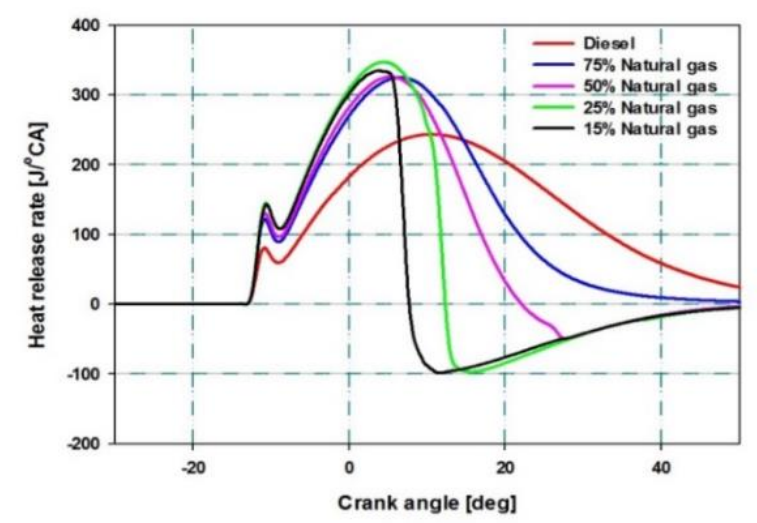

Figure 12. Effect of different amount of natural gas addition on heat release rate.

Heat release rate is an important indicator of combustion efficiency. This particular parameter helps to explain the changes in performance, combustion and emission. There are four phases of conventional diesel engine combustion: ignition delay, premixed or rapid combustion phase, mixing controlled combustion phase, and late combustion phase [19]. Figure 12 shows the effect of natural gas addition on heat release rate in each crank shaft degree. The peak heat release rate of dual-fuel combustion was slightly higher and main combustion duration was shorter than the ones of diesel mode. The maximum heat release rate was 243.5 Joules per degrees of crank angle $\left(\mathrm{J} /{ }^{\circ} \mathrm{CA}\right), 334.9 \mathrm{~J} /{ }^{\circ} \mathrm{CA}, 347.1 \mathrm{~J} /{ }^{\circ} \mathrm{CA}, 326.1 \mathrm{~J} /{ }^{\circ} \mathrm{CA}$ and 324.9 $\mathrm{J} /{ }^{\circ} \mathrm{CA}$ for diesel, $15 \%, 25 \%, 50 \%$ and $75 \%$ natural gas 
addition respectively. The maximum heat release rate increased by $37.5 \%, 42.5 \%, 33.8 \%$ and $33.4 \%$ for $15 \%$, $25 \%, 50 \%$ and $75 \%$ natural gas addition respectively; when compared with diesel fuel mode. During dual-fuel combustion mode, most of the diesel fuel is replaced by natural gas and the ignition delay is longer, there is a few or no mixing controlled combustion.

\section{Conclusions}

A simulation was carried out in GT-power engine simulation software to investigate the performance and emission characteristics of a turbocharged 6-cylinder engine using diesel and diesel-natural gas fuel. The diesel fuel mode engine and dual fuel mode engine were compared in terms of brake specific fuel consumption, BTE and emissions of $\mathrm{CO}, \mathrm{CO}_{2} \mathrm{NO}_{x}$, and $\mathrm{HC}$. Moreover Combustion characteristic related with In-cylinder gas pressure and heat release rate were also investigated. The results can be summarized as follows:

1. It was observed that the brake specific fuel consumption under dual fuel conditions were higher when compared to original diesel mode operation. The BSFC increased by $147 \%, 67 \%, 40 \%$ and $27 \%$, respectively, with addition of $15 \%, 25 \%, 50 \%$, and $75 \%$ natural gas compared to only neat diesel fuel mode.

2. It was also observed that the brake thermal efficiency was generally lower during dual-fuel operation than diesel fuel mode. The BTE values decreased by $62.9 \%$, $46 \%, 36 \%$ and $30 \%$ for $15 \%, 25 \%, 50 \%$ and $75 \%$ natural gas addition respectively.

3. It was found that in dual fuel mode $\mathrm{NO}_{\mathrm{X}}$ emissions reduced significantly. The NOx emissions decreased by $62 \%, 58 \%, 52 \%$, and $47 \%$ respectively, for $15 \%, 25 \%$, $50 \%$, and $75 \%$ natural gas addition compared to only diesel fuel mode.

4. $\mathrm{HC}$ and $\mathrm{CO}$ emissions increased by more than $150 \%$ and $100 \%$ respectively with natural gas addition compared to only diesel fuel. While $\mathrm{CO}_{2}$ emissions decreased by $59 \%, 53.8 \%, 51.4 \%$, and $49 \%$ for $15 \%$, $25 \%, 50 \%$ and $75 \%$ natural gas addition compared to only diesel fuel mode.

$\begin{array}{ll}\text { Nomenclature } & \\ Q_{\text {comb,tal }} & \text { Total heat released } \\ Q_{\text {comb,NG }} & \text { Heat released by natural gas } \\ Q_{\text {comb,D }} & \text { Heat released by pilot diesel fuel } \\ \dot{E} & \text { The total energy } \\ \dot{W} & \text { Rate of Work transfer } \\ \dot{Q} & \text { Rate of heat transfer } \\ \dot{m}_{i} & \text { Mass flow rate } \\ h_{i} & \text { Enthalpy change } \\ \dot{m}_{\mathrm{D}} & \text { diesel fuel mass } \\ \dot{m}_{N G} & \text { Natural gas fuel mass } \\ d Q_{\mathrm{n}} & \text { Apparent heat release rate } \\ d Q_{h t} & \text { Heat lost to the cylinder walls } \\ P & \text { Pressure } \\ R & \text { Gas constant } \\ T & \text { Temperature } \\ \mathrm{P}_{\mathrm{b}} & \text { Brake engine power } \\ T_{\mathrm{g}} & \text { The gas instantaneous temperature } \\ T_{\mathrm{w}} & \text { Cylinder wall temperature } \\ A & \text { Cylinder heat transfer area } \\ & \end{array}$

$\begin{array}{ll}h_{\mathrm{g}} & \text { Heat transfer coefficient } \\ V & \text { The total volume } \\ \mathrm{v} & \text { Specific volume } \\ \gamma & \text { Ratio of specific heats } \\ u & \text { Characteristic velocity } \\ B & \text { Cylinder bore diameter } \\ \mathrm{BTE} & \text { Brake thermal efficiency } \\ { }^{\circ} \mathrm{CA} & \text { degrees of Crank angle } \\ \mathrm{CO} & \text { Carbon monoxide } \\ \mathrm{CO} & \text { Carbon dioxide } \\ \mathrm{NO} & \text { Nitrogen oxides } \\ \mathrm{HC} & \text { Hydrocarbon } \\ \mathrm{LHV} & \text { Lower heating value of natural gas } \\ \mathrm{LHV} & \text { Lower heating value of diesel fuel } \\ \mathrm{BSFC} & \text { Brake specific fuel consumption } \\ \mathrm{ppm} & \text { Parts per million } \\ u_{\mathrm{D}} & \text { Effective heat of combustion D } \\ u_{\mathrm{NG}} & \text { Effective heat of combustion NG } \\ \tau_{\mathrm{D}} & \text { Normalized time for pilot fuel } \\ \tau_{\mathrm{NG}} & \text { Normalized time for NG } \\ \theta_{0 \mathrm{D}} & \text { Start of combustion for Diesel } \\ \theta_{\mathrm{bD}} & \text { Combustion duration for Diesel } \\ \theta_{0 \mathrm{NG}} & \text { Start of combustion for NG } \\ \theta 0 \mathrm{D} & \text { Combustion duration for NG } \\ \mathrm{NG} & \text { Natural gas } \\ \mathrm{D} & \text { Diesel } \\ & \end{array}$

\section{References:}

[1] H. Bayraktar, "An experimental study on the performance parameters of an experimental CI engine fueled with diesel-methanol-dodecanol blends," Fuel, $87,158-164,2008$.

[2] J. Liu, A. Yao, and C. Yao, "Effects of injection timing on performance and emissions of a HD diesel engine with DMCC," Fuel, 134, 107-113, 2014.

[3] A. Broatch, J. Luján, S. Ruiz, and P. Olmeda, "Measurement of hydrocarbon and carbon monoxide emissions during the starting of automotive DI diesel engines," Int. J. Automotive Technol., 9, 129-140, 2008.

[4] MARPOL Annex IV ,Regualtion 13 ,International Maritime Organization, [Online], Available: www.imo.org/en/OurWork/Environment/PollutionPrev ention/AirPollution/Pages/Nitrogen-oxides-(NOx)\%E2\%80\%93-Regulation-13.aspx (accessed April 10, 2017).

[5] B. Sahoo, N. Sahoo, and U. Saha, "Effect of engine parameters and type of gaseous fuel on the performance of dual-fuel gas diesel engines-A critical review," Renewable and Sustainable Energy Reviews, 13, 1151-1184, 2009.

[6] O. Badr, G. Karim, and B. Liu, "An examination of the flame spread limits in a dual fuel engine," Applied Thermal Eng., 19, 1071-1080, 1999.

[7] J. Kusaka, T. Okamoto, Y. Daisho, R. Kihara, and T. Saito, "Combustion and exhaust gas emission characteristics of a diesel engine dual-fueled with natural gas," JSAE Review, 21, 489-496, 2000. 
[8] G. A. Alla, H. Soliman, O. Badr, and M. A. Rabbo, "Effect of pilot fuel quantity on the performance of a dual fuel engine," Energy Conversion Management, 41, 559-572, 2000.

[9] Y. Karagöz, T. Sandalcı, U. O. Koylu, A. S. Dalkılıç, and S. Wongwises, "Effect of the use of natural gasdiesel fuel mixture on performance, emissions, and combustion characteristics of a compression ignition engine," Advances in Mechanical Engineering, 8, 1-13, 2016.

[10] R. Papagiannakis and D. Hountalas, "Combustion and exhaust emission characteristics of a dual fuel compression ignition engine operated with pilot diesel fuel and natural gas," Energy conversion and Management, 45, 2971-2987, 2004.

[11] J. Egúsquiza, S. Braga, and C. Braga, "Performance and gaseous emissions characteristics of a natural gas/diesel dual fuel turbocharged and aftercooled engine," J. Brazilian Soc. Mech. Sci. Eng., 31, 142150, 2009.

[12] V. K. Gaba and P. Nashine, " Combustion Modeling of Diesel Engine Using Bio-Diesel as Secondary Fuel," International Conference on Mechanical and Robotics Engineering(ICMRE'2012),89-

93,Phuket,Thailand,2012

[13] V. Ayhan, A. Parlak, I. Cesur, B. Boru, and A. Kolip, "Performance and exhaust emission characteristics of a diesel engine running with LPG," Int. J. Phys. Sci., 6, 1905-1914, 2011.

[14] A. Kumaraswamy and B. D. Prasad, "Performance analysis of a dual fuel engine using LPG and diesel with EGR system," Procedia Eng., 38, 2784-2792, 2012.

[15] Bob-Manuel, K. and Crookes, R., "Performance and Emission Evaluation in Dual-Fuel Engine Using Renewable Fuels for Pilot Injection," SAE Technical Paper2007-01-3605,2007,https://doi.org/10.4271/200701-3605.

[16] R. Singh and S. Maji, "Performance and exhaust gas emissions analysis of direct injection cng-diesel dual fuel engine," International Journal of Engineering Science and Technology, 4, 833-846, 2012.

[17] P. L. Mtui, "Performance And Emissions Modeling Of Natural Gas Dual Fuelling Of Large Diesel Engines," Int. J. Sci. Technol. Res., 2,317-323, 2013.

[18]C. R. Ferguson and A. T. Kirkpatrick, Internal combustion engines Applied Thermosciences, New York John Wiley \& Sons, 2015.

[19] J.B.Heywood,Internal Combustion Engine Fundamentals, New York: McGraw-Hill, 1988.

[20] G. A. Karim, Dual-fuel diesel engines,Florida: CRC Press, 2015.

[21] G. Theotokatos, S. Stoumpos, I. Lazakis, and G. Livanos, "Numerical study of a marine dual-fuel fourstroke engine," In Proceedings of 3rd International Conference on Maritime Technology and Engineering(MARTECH2016),777-786, Lisbon, 2016.
[22] A. Medina, P. L. Curto-Risso, A. C. Hernández, L. Guzmán-Vargas, F. Angulo-Brown, and K. S. Asok, Quasi-dimensional simulation of spark ignition engines, london:Springer,pp.40-41,2013.

[23]H. Köse and M. Ciniviz, "An experimental investigation of effect on diesel engine performance and exhaust emissions of addition at dual fuel mode of hydrogen," Fuel Proces. Technol., 114, 26-34, 2013.

[24] W. A. Majewski and M. K. Khair, Diesel emissions and their control, Michigan: SAE International,2006.

[25] K. Cheenkachorn, C. Poompipatpong, and C. G. Ho, "Performance and emissions of a heavy-duty diesel engine fuelled with diesel and LNG (liquid natural gas)," Energy, 53, 52-57, 2013.

[26] M. Abdelaal and A. Hegab, "Combustion and emission characteristics of a natural gas-fueled diesel engine with EGR," Energy Conversion Management, 64, 301312, 2012.

[27] R. Papagiannakis, C. Rakopoulos, D. Hountalas, and D. Rakopoulos, "Emission characteristics of high speed, dual fuel, compression ignition engine operating in a wide range of natural gas/diesel fuel proportions," Fuel, 89, 1397-1406, 2010.

[28] J. Liu, F. Yang, H. Wang, M. Ouyang, and S. Hao, "Effects of pilot fuel quantity on the emissions characteristics of a CNG/diesel dual fuel engine with optimized pilot injection timing," Applied Energy, 110, 201-206, 2013.

[29] S. Imran, D. Emberson, A. Diez, D. Wen, R. Crookes, and T. Korakianitis, "Natural gas fueled compression ignition engine performance and emissions maps with diesel and RME pilot fuels," Applied Energy, 124, 354-365, 2014.

[30] G. A. Karim, "A review of combustion processes in the dual fuel engine - the gas diesel engine," Progress in Energy and Combustion Science, 6, 277-285, 1980.

[31] M. S. Lounici, K. Loubar, L. Tarabet, M. Balistrou, D.C. Niculescu, and M. Tazerout, "Towards improvement of natural gas-diesel dual fuel mode: An experimental investigation on performance and exhaust emissions," Energy, 64, 200-211, 2014.

[32] Kouremenos, D., Hountalas, D., and Kouremenos, A., "Experimental Investigation of the Effect of Fuel Composition on the Formation of Pollutants in Direct Injection Diesel Engines," SAE Technical Paper 1999. 01-0189, 1999, https://doi.org/10.4271/1999-01-0189.

[33] T. Gatts, S. Liu, C. Liew, B. Ralston, C. Bell, and H. $\mathrm{Li}$, "An experimental investigation of incomplete combustion of gaseous fuels of a heavy-duty diesel engine supplemented with hydrogen and natural gas,Int. J. Hydrogen Energy, 37, 7848-7859, 2012.

[34] R. Papagiannakis and D. Hountalas, "Experimental investigation concerning the effect of natural gas percentage on performance and emissions of a DI dual fuel diesel engine," Applied Thermal Eng., 23, 353365, 2003.

[35]E. Ramjee, K. Reddy, B. Kumar, and M. Basha, "Analysis of Emission characteristics on Compression 
Ignition Engine using Dual Fuel Mode for Variable Speed," Int. J. Eng. Res. Dev., 4, 23-27, 2012.
[36] O. Nwafor, "Effect of advanced injection timing on emission characteristics of diesel engine running on natural gas," Renewable Energy, 32, 2361-2368, 2007. 